\title{
Enhancing Students' Performance in ELT Programs in the Credit-Based Training System
}

\author{
Le Thi Thanh Truc \\ Thua Thien Hue College of Education, Vietnam \\ bambookl@gmail.com
}

\begin{abstract}
In recent years, there has been a trend among Vietnamese universities and colleges to shift from the academic year training system to a credit-based one. Despite the many positive sides the new system is supposed to bring about, students in reality are facing varied challenges due to inadequate preparation for the new learning mode, which requires students to take greater responsibility for their learning. This paper reports on the results of a study designed to help train first-year students of English to become independent learners so as to be successful in credit-based education. After the students had carried out the four activities introduced in the study, namely making study plans, going on field trips, exchanging letters with peers, and selfevaluating their progress over one semester, their performance was enhanced to various extents, depending on their commitment and capacity.
\end{abstract}

Over the past few decades, Vietnam has made dramatic progress in various fields such as economics, politics, education, and culture. Accordingly, there have been increasingly bigger demands for qualified manpower. As the provider of the required human resource, Vietnamese education has undergone several reforms so as to fulfill its mission, most noticeably since the late 1980s after the renovation period known as đổi mới was introduced. The mono-disciplinary and disconnected colleges and universities popular before đổi mới were merged to create multidisciplinary colleges during the 1990s. At the same time, the traditional teacher-centered approach was disregarded and the learner-centered approach was promoted instead. More recently, the academic year training system has been gradually replaced by the credit-based system.

Each kind of reform brings about both opportunities and challenges for those involved. The credit system definitely has its strengths, yet there remain problems to be addressed and solved. This paper focuses on the attempts made by the researcher to help her first-year students of English perform successfully in an English language teaching (ELT) program which is based on credits.

\section{Overview of the Credit System}

According to Lam (2006), the credit system was first introduced at Harvard University in 1872; it quickly spread to universities all over America and then to universities in North America, Asia, and other parts of the world. In 1999, the Bologna Declaration was signed by ministers of education of 29 European countries, adopting the European Credit Transfer System (ECTS) with a view to providing greater mobility and transferability for students in Europe.

Language Education in Asia, 2010, 1(1), 133-146. http://dx.doi.org/10.5746/LEiA/10/V1/A12/Le 
In Vietnam, the Ministry of Education and Training (MOET) encouraged universities to apply the credit system from the academic year 1993-1994; since then, there have been more and more universities using this system (Lam, 2006). "Planning on the network of Vietnam's universities and colleges in the 2001-2010 period" proposed a gradual movement from the academic year system to the credit system (Prime Minister's Decision No. 47/2001-QD-TTG, 2001). Most recently, this aim was reinforced with an emphasis on the quick expansion of credit system adoption among universities, colleges and vocational schools immediately from the academic year 2005-2006. The target was that by 2010, a majority of universities and colleges would have applied this form of training (Report on Educational Conditions, 2004).

\section{Definition of the Credit System}

The credit system is a systematic way of administering an educational program by attaching credits to its components. An academic credit can be defined as "the unit by which an institution may measure its course work. The number of credit hours assigned to a course is usually defined by the number of hours per week in class" (National Center for Educational Statistics [USA], 1968, as cited in Regel, 1992, p. 3). A credit-based curriculum is defined as one that consists of core subjects and electives that constitute academic majors (Mason, Arnove, \& Sutton, 2001).

\section{Academic Year System vs. Credit System}

The table below presents some basic distinguishing features between the academic year system and the credit system currently applied in Vietnamese higher education institutes. It should be noted that the total workload/program shown is the minimum average since the numbers may vary slightly according to the kind of college or university.

\section{Table 1}

Distinguishing Features of the Academic Year System and the Credit System

\begin{tabular}{|l|l|l|}
\hline \multicolumn{1}{|c|}{ Features } & \multicolumn{1}{|c|}{ Academic year system } & \multicolumn{1}{c|}{ Credit system } \\
\hline Measurement unit & Academic unit & Credit \\
\hline $\begin{array}{l}\text { Total workload/program } \\
+ \text { Three-year course } \\
+ \text { Four-year course }\end{array}$ & $\begin{array}{l}160 \text { academic units } \\
210 \text { academic units }\end{array}$ & $\begin{array}{l}110 \text { credits } \\
140 \text { credits }\end{array}$ \\
\hline Contact hours & $\begin{array}{l}15 \text { 45-minute periods per } \\
\text { academic unit }\end{array}$ & 15 50-minute periods per credit \\
\hline Curriculum & Core subjects only & Core subjects + electives \\
\hline Syllabus & Flexible, general & $\begin{array}{l}\text { Fixed, detailed, delivered to } \\
\text { students on the first session or } \\
\text { before }\end{array}$ \\
\hline Completion time & Fixed & $\begin{array}{l}\text { Earlier or later than the academic } \\
\text { year system }\end{array}$ \\
\hline
\end{tabular}




\section{Literature Review}

The credit system is believed to be more advantageous than the academic year system in terms of learning effectiveness, flexibility/responsiveness, and cost effectiveness/management (Regel, 1992). However, in the initial stage of its application in Vietnam, there remain many problems, as identified by Thai (2005), including the improperly structured curriculums, limited time devoted to research for innovative teaching methodologies, insufficient feedback from learners and employers, inexperienced and under-trained course advisors, lack of guiding documents by MOET, limited resources and facilities, and students' unfamiliarity with the new learning mode.

In the field of English teaching and learning, efforts have been made to help students perform successfully in the credit-based system. For example, at Hue University of Foreign Languages, a learner-self management model has been adopted in order to improve students' English language skills (Pham 2009, 2010). Nonetheless, such attempts are still limited.

\section{Rationale}

While the limitations of a credit-based framework cannot be overcome overnight as they require the time, effort, and cooperation of different parties, individual teachers/lecturers can act to help their students become better prepared to meet the new, challenging learning requirements. In other words, the teacher can train students to take responsibility for their learning right from the beginning of their program at college. In addition, since in the credit system students are expected to perform numerous tasks outside class hours, they need to be independent and active in their learning. These facts prompted the author to conduct this study.

\section{The Study}

\section{Participants}

The research subjects included 48 first-year students training to be teachers of English for primary and lower secondary schools in one class at Thua Thien Hue College of Education, Hue City, Vietnam. Their course lasts three years. All of them had between 6 to 10 years of learning English from primary school or lower secondary school. They had different starting times for learning English, depending on the availability of English courses offered at the schools they attended. The majority of the students came from rural areas within Thua ThienHue Province or from the poor neighboring provinces. These students did not attend or pass the entrance exam to the university where four-year courses are offered to train them to be teachers of English for upper secondary schools. Their English scores in the entrance exam to college ranged from 4.0 to 8.0, which means some students might have passed the exam because their math and/or literature scores, not their English scores, were high. They all claimed that they had good intrinsic and/or extrinsic motivation to learn English. Outside the classroom, students mainly did grammar exercises, went to extra classes, or crammed for entrance exams to university or college. The main challenge they identified when learning English was the lack of effective learning methods.

\section{Selection of Activities}

The framework for the choice of the activities introduced in this study comprises the C-R-E-A-M strategies for learning suggested by Cottrell (2003): 


\section{C - Creative}

Have the confidence to use individual strategies and learning styles, applying imagination to your learning

\section{R - Reflective}

Be able to sit with your experience, analyze and evaluate your own performance, and draw lessons from it

E - Effective

Organize your space, time, priorities, state of mind and resources [including information technology (IT)] to the maximum benefit

\section{A - Active}

Be personally involved and doing things, physically and mentally, in order to make sense of what you learn

M - Motivated

Be aware of your own desired outcomes; keep yourself on track using short- and long-term goals.

Cottrell (2003, p. 59)

Since it was infeasible and ineffective to carry out a wide range of activities within the time constraints, only four activities were selected to introduce to students: study plans, field trips, letter exchanges, and self-evaluation. Explanations for the choice of these particular activities will be given in the sections below.

Activity 1: Study plans. This activity was designed to employ the E (Effective) C-R-E-A-M strategy for learning. To become effective learners, Cottrell (2003) suggests that students must know how to make good use of their time. In reality, failing to meet deadlines or unsuccessfully completing tasks due to poor time management are common problems among students. When the training mode is switched from the academic year system in which the teacher controls students' learning quite closely to the credit-based one in which at least onethird of the total time is allocated to self-study, it is crucial for students to manage their time effectively. Making study plans was believed to help students better arrange time to carry out their studies successfully.

Activity 2: Field trips. This activity was designed to use the A (Active) C-R-E-A-M strategy. To become active learners, students need to act. Field trips were included in the study because the researcher believed that "travel broadens the mind" and trains students to be active. In addition, from the researcher's observations, the routine of about two-thirds of first-year students was basically movement between school and home. Rarely did they take the initiative to go out to see what was happening in the outside world or what was available to them. Most of the time, they waited for the teachers to instruct them on what to do.

Activity 3: Letter exchanges. This activity was designed to employ the C (Creative) C-R-E-A-M strategy. To become effective learners, students should identify their learning strategies, which are classified by Oxford (1990) under six categories, namely memory, cognitive, compensation, metacognitive, affective, and social strategies. As a social strategy, exchanging letters with peers was seen as an effective way to improve English language skills, mainly writing skills, because students had to think and communicate their ideas to their partners in English. Furthermore, this activity involves cooperative learning, which plays an important role 
in students' successful performance, since in the credit system, students need to spend a considerable amount of time working with peers.

Activity 4: Self-evaluation: Monitoring skills development. This activity was designed to utilize the R (Reflective) C-R-E-A-M strategy. To become reflective learners, Cottrell (2003) lists five methods for developing reflection, which are keeping a learning journal, using self-evaluation sheets, keeping an updated profile or portfolio, making constructive use of feedback, and filling in progress sheets regularly. As most Vietnamese students are not familiar with reflection and therefore can find it hard to reflect without guidance, using self-evaluation sheets was chosen to facilitate students' reflection processes.

A letter from Cottrell's framework that seems to be missing from this list of activities is $M$, for Motivation. However, the four activities introduced in this study all work towards increasing students' motivation. For example, being motivated involves reflection upon what students want. Active learning and good organization strategies require motivation, and also help students stay motivated.

\section{Delivery of Activities}

The activities in this study were supplementary, designed and conducted to enhance students' performance when they first started academic life at college. The activities were not part of the curriculum. Students' participation was compulsory, but was not to be graded. The four activities were introduced to students during the first semester of Year 1.

In the first week, students were introduced to Activity 1 : study plans. For each of the remaining weeks of the first semester, they were required to fill in the study plan (see Appendix A) with tasks, set by their teachers or themselves, which would need to be done during the week. At the end of each day, students had to reflect upon what they had done and decide whether they had successfully or unsuccessfully completed what they had planned to cover. If they failed to do an activity, they would need to give an explanation. They were asked to hand in their plans and feedback on the activity on a weekly basis.

Also in Week 1, students were introduced Activity 2: field trips. The first field trips suggested in this study were just short, easy-to-make ones to help students break their daily routines of staying within the four walls of either their rooms at home or classrooms at college. For example, a field trip could be a visit to bookstores to see what books were available for a particular skill, a visit to a newly opened supermarket just across the road from the campus to observe what was on sale there, or even more simply, a tour around the college to find the Vietnamese and English names of the rooms in the administrative building. Later on, destinations could include landmarks of the city such as the Citadel, the royal tombs, or pagodas. Students could take the trips at the time convenient to them. They were allowed to go on field trips by themselves, in pairs, or in groups. Before the tours, they had to make plans of where and when to go, and what they expected to see and do at the places. After the trips, they were asked to write reports and hand them in to the teacher.

In Week 5, students started to perform Activity 3: letter exchanges. To carry out the activity, each of the students was asked to choose one classmate as a language partner. Every day, they had to write one letter in English to their partners on topics of their own choice; the length of the letter was not stipulated. Then the students exchanged letters with their partners. They were also required to write one letter to their teacher every week, stating their feelings about the activity or any issue of concern to them. This activity lasted 10 weeks. Students received 
general feedback from the teacher every week and their questions and worries were dealt with as a class or individually.

Also in Week 5, students were asked to carry out Activity 4: self-evaluation, in which they had to fill in the evaluation sheet (see Appendix B). For the duration of 10 weeks, students were asked to reflect upon their English skills, identifying at least three areas they would like to improve and taking actions to improve them. They had to hand in the evaluation sheets, plus their feedback on the activity every three weeks.

\section{Findings and Discussion}

The following findings were based on students' ongoing feedback on each activity during the semester and responses to an open-ended questionnaire given at the end of the semester to gain students' comments and preferences on the activities introduced.

\section{Activity 1: Study Plans}

All of the students made study plans and handed them in to the teacher in charge on every Friday afternoon for the first five weeks. Nonetheless, in the following weeks, about $30 \%$ of the students failed to do so or handed in plans which were carelessly completed.

All of the students taking part in the study revealed that they had never made study plans before. For them, the new experience was useful not only for their studies, but in their daily lives. Forty-five out of forty-eight students believed that making study plans helped them have an overview of their weekly workload and plan tasks in advance. As a result, they were able to perform or complete their tasks better than in the past. One student claimed, "The activity helped me form good learning habits. With the proper allocation of time for different tasks, it was easier for me to carry out and keep track of my study activities." Another stated, "The activity trained me to make effective use of time and be stricter with myself." Another student confessed, "I did not make plans regularly, yet now that the end-of-semester exam is coming near, I am thinking about doing it because I believe it helps me prepare for the exam better."

However, one third of the students said they found making study plans a repetitive, timeconsuming task. They also complained that it was hard to complete the planned tasks. Toward the end of the semester, these students felt that the activity had become a burden. They explained that their lack of motivation and time prevented them from producing detailed, wellwritten plans.

From students' feedback, it can be seen that making study plans did help students to better manage their time and organize their studies. However, maintaining the habit, particularly when under time pressure, could be hard for certain students. In addition, there were students who were unaware that the ultimate aim of making study plans was to train them to be better at time management, not to produce perfectly looking but unrealistic plans. For the activity to be more attractive, students can keep a diary in which all personal, leisure and academic activities are included using not only words but also color codes and symbols.

\section{Activity 2: Field Trips}

Students completed the first three trips with excitement and no difficulty. In the first week, they visited bookstores in the city and made a list of the books available on one of the four language skills. For over two-thirds of the students who came from the countryside or the poor provinces, it was their first visit to such big bookstores, which really fascinated them. Even for urban students, the visit brought them interesting experiences. One student reported, "I had 
been to the bookstores so many times before but not until I made the list of reference books did I realize how many books there were. How surprising!"

Similarly, the visit to the new supermarket captured students' interest. For the majority of the students, it was an enjoyable leisure activity rather than a serious task set by the teacher and they made the visit voluntarily and eagerly. One group of students even went to all the four supermarkets in the city and made a comparison of what was on sale in each one.

The tour around the college was also useful to students, as one student commented, "Thanks to the exercise, we now have an orientation of the location of functional departments and know where to go to when we need to contact them."

The destinations students chose for their later trips were within walking or bicycle riding distances, such as the river banks, the city square, the famous bridge, markets, or pagodas within the city. Only three groups paid visits to free admission tourist attractions in a suburb just around 7 kilometers away from the city center. The reasons for their choices were the lack of transport means and inability to afford admission fees.

In general, the students' feedback on field trips was positive. Indeed, this was their most favorite activity of the four introduced. They found the field trips highly enjoyable and relaxing. At the same time, they claimed that going on field trips helped them become more active, more confident, and more motivated since they had opportunities to learn about or discover interesting things as well as to understand their classmates better. However, while all of the students could easily complete the list of reference books, description of the new supermarket, and names of the administrative rooms, over $70 \%$ of the students had to struggle with the reports from trips to the local landmarks. Only 13 students with strong competence in English could write relatively good reports (see Appendix C) and were happy with the post- field trip writing activity.

The teacher also encouraged students to share their reports by helping them set up an email account for the class and assisting them in creating an email account for themselves. However, only five students who had access to the Internet at home posted reports. The rest said they were not familiar with emails or could not afford the Internet cost outside the college, while the limited number of computers in the college library allowed students to access only certain websites.

Field trips are usually a very popular activity which most people enjoy. The ones introduced might sound boring to some people, but for freshmen, in particular those from disadvantaged backgrounds, the small trips were crucial in getting them out of their shells and building up their confidence. The field trips serve as a starting point for longer, more adventurous study tours that these students could take in the future.

\section{Activity 3: Letter Exchanges}

Writing five letters to a partner and one letter to the teacher in English per week was a real challenge for most students. In the first three weeks, students always complained about the heavy workload of letter writing. They reported that they had to spend too much time thinking about the topic and the content of each letter. Even when the teacher helped them brainstorm a list of topics which they could write about, they still had to struggle with expressing themselves in English. In the following weeks, while about half of the students managed to continue writing the requested number of letters seriously, the rest started to reduce the number of letters written each day or wrote short and simplistic ones. Samples of students' letters can be found in Appendix D. 
Students had quite positive feedback in their evaluations. In general, they wrote that they enjoyed the activity very much. They mentioned that after 10 weeks, they could write more easily and quickly, had a wider vocabulary, were more confident with grammar and sentence structures, had improved skills in general, understood their partners better, and had more motivation to learn English. However, they also stated the difficulties in carrying out the activity. Lack of ideas, lack of partner cooperation, and demotivation when failing to express ideas in English were identified as the three biggest challenges they faced when writing letters to partners in English.

The students' feedback confirms the benefits of letter exchanges as a way for students to familiarize themselves with writing in English and have authentic communication in English. The activity was supposed to provide them with opportunities to use English, to think in English, and to be exposed to English as much as possible. The primary aim was not for them to write perfect letters, but to develop fluency in writing. In addition, brainstorming writing topics with peers or using L1 words or phrases occasionally in the letters could facilitate the writing process. Students should also be serious about their writing so as to avoid wasting their own time and frustrating their partners.

\section{Activity 4: Self-Evaluation: Monitoring Skills Development}

Students claimed that they needed to develop all of the four skills and therefore chose one skill to develop each time. When first completing the self-evaluation form, they all reported a very low or low level of confidence in the skill chosen and mentioned hardly anything about the aspects of the skill they had already demonstrated. The goal they set for themselves was generally improving their speaking, writing, reading, or listening skills without providing further details of the aspects, sub-skills or qualities they wanted to develop, even though the teacher had provided a demonstration. As a result, they were not able to notice the progress that they had made. Later on, with more careful guidance from the teacher, especially for weak students, the students gradually gained more confidence and managed to produce a more detailed evaluation (see Appendix E).

According to the students' feedback, they found the reflection activity useful because it helped them to become aware of their strengths and weaknesses and make some progress in their learning. However, they complained that it was hard to write specific goals without the teacher's guidance, that it took quite a while to notice progress, and most seriously, they felt demotivated when identifying too many weaknesses or when failing to make quick progress. In addition, the heavy workload they had each week prevented them from totally devoting their time to the activity.

For the students, who were used to a passive learning style in which everything had been instructed by the teacher, it was indeed a daunting task having to identify weaknesses and making action plans tailor-made for them to improve their skills. However, as practice makes perfect, with patience, effort, and support from the teacher and peers, students were able to overcome initial difficulties and make progress.

\section{Implications}

From the discussion of the findings, the following implications are made.

Firstly, different students might like different activities due to their different learning styles and levels of English proficiency. It is therefore impossible to expect all students to support a certain activity. Offering students choices seems to work best and helps students maintain motivation. 
Secondly, for activities to be effective, teachers need to be aware of students' overall workload and know what amount of work average students can handle with success. Only by giving a manageable workload can students complete tasks well over long periods of time. In addition, it is suggested that these activities be introduced to students as early as possible in the program. However, great care needs to be taken so that students do not feel overwhelmed and therefore lose motivation.

Thirdly, understanding what benefits they will have in the long term when being engaged in certain activities makes students more motivated and ready to perform their tasks. Timely encouragement and feedback are also essential for having the desired outcomes.

Fourthly, modifications of activities for different contexts are recommended. Inclusion of or reference to technological services available such as email or blogs can accommodate the needs of students and increase their motivation.

Finally, consulting colleagues and experts in the field for suggestions and implementation of further activities is of great importance since these people are rich sources of ideas and experience and can offer useful advice or recommendations.

\section{Conclusion}

Although the activities in this study were introduced to first-year students at college with an aim to facilitate their transition from high school to college, they can be applicable to students of all ages and levels. Due to time constraints and the small size of the sample, generalizations cannot be made from the results of the study. However, the activities have great value in that they show the kinds of interventions teachers with limited resources can implement. These activities are indeed easy to carry out, which is crucial in contexts where resources are restricted, students' backgrounds are disadvantaged and teachers' workload is too heavy.

\section{Biodata}

Le Thi Thanh Truc has been a lecturer of English at Thua Thien Hue College of Education since 1997. She earned her Master's degree in TESOL from the University of Melbourne, Australia, in 2003. Her current research interests include quality assurance, professional development, selfdirected learning, cooperative learning, and curriculum design.

\section{References}

Cottrell, S. (2003). The study skills handbook (2 ${ }^{\text {nd }}$ ed.). New York, NY: Palgrave Macmillan.

Lam, Q. T. (2006, February). Về việc áp học chế tín chi trên thế giới và ở Việt Nam [About the application of the credit-based system in the world and in Vietnam]. Retrieved from the National University of Hanoi, News and Events website: http://news.vnu.edu.vn/ttsk/Vietnamese/C1736/C1750/C1880/2006/05/N10148/?35

Mason, T. C., Arnove, R. S., \& Sutton, M. (2001). Credits, curriculum, and control in higher education: Cross-national perspectives. Higher Education, 42(1), 107-137. http://dx.doi.org/10.1023/A:1017525003769

Oxford, R. (1990). Language learning strategies: What every teacher should know. Boston, MA: Heinle and Heinle.

Pham, T. H. N. (2009). Improving EFL Students' Practical Skills: A Learner Self Management Model. Paper presented at National Conference on Language Teaching Methodology. Hue University of Foreign Languages, Hue City, Vietnam. 
Pham, T. H. N. (2010). Toward a Learner Self Management Model in Teaching English Language Skills in Credit-based EFL Programmes: The Case of Hue University of Foreign Languages. Paper presented at the International Conference on Innovations in Language Teaching and Learning. Hochiminh City, Vietnam

Prime Minister's Decision No. 47/2001/QD-Ttg. (2001). Quyết định của Thủ tướng chính phủ số 47/2001/QĐ-Ttg ngày 04 tháng 4 năm 2001 phê duyệt "Quy hoạch mạng lưới trường đại học, cao đẳng giai đoạn 2001-2010" [Prime Minister's Decision No. 47/2001/QD-Ttg, dated April 4, 2001, approving "Planning on the network of Vietnam's universities and colleges in the 2001-2010 period"]. Hanoi, Vietnam.

Regel, O. (1992). The academic credit system in higher education: Effectiveness and relevance in developing countries. Washington, DC: World Bank.

Report on Educational Conditions. (2004). Báo cáo tình hinh giáo dục [Report on Educational Conditions]. Report presented at the National Assembly meeting by the Government in October 2004. Hanoi, Vietnam.

Thai, K. D. (2005). Đào tạo theo hệ thống tín chỉ: Kinh nghiệm thế giới và thực tế ở Việt Nam. [Credit training system: World experience and Vietnamese reality]. Paper presented at the conference on credit training system of the University of HUFLIT, Vietnam. Retrieved from http://www.ier.edu.vn/content/view/110/161

\section{Appendix A}

Study Plan

FULL NAME:

\begin{tabular}{|l|l|l|}
\hline Day/date & Activity & \\
\hline & & \\
\hline & & \\
\hline & & \\
\hline & & \\
\hline & & \\
\hline & & \\
\hline & & \\
\hline
\end{tabular}

Date:

Signature: 


\section{Appendix B \\ Self-Evaluation Sheet}

Self-evaluation: Monitoring skills development

Date: Skills being developed:

My current level of confidence in this skill (circle 1)

1 very low 2 low 3 ok 4 high 5 very high

Aspect of this skill I have already demonstrated

Goal

What I want to be able to do (aspects, sub-skills, qualities I want to develop):

Record of progress

Note down steps in your development of this skill. It is up to you to decide what progress means for you. It could be the achievement of a personal goal (such as getting a particular mark for an assignment), or a small step towards one of your goals (such as asking a question in class for the first time, or developing a successful strategy for arriving on time if you find time management is a challenge.)

\begin{tabular}{|l|l|l|}
\hline Date & \multicolumn{1}{|c|}{ Achievement } & \multicolumn{1}{|c|}{ How you know } \\
\hline & $\begin{array}{l}\text { (What I can do now that I couldn't } \\
\text { before) }\end{array}$ & (evidence or example) \\
\hline & & \\
\hline & & \\
\hline & & \\
\hline
\end{tabular}




\section{Appendix C}

\section{Sample Field Trip Report}

Location: Dong Ba Market

Time: 2 pm, Thursday afternoon, December 31, 2009

Group members: Thanh Tuyen + Thuy Phuong

Expected things/activities: crowds, a lot of food and clothes for the new year, shopping for new clothes

This afternoon, we went to Dong Ba Market as planned. We intended to meet at the college gate at $2 \mathrm{pm}$ but Phuong's bicycle broke down and she came late. So we started at 2.30 instead. We went to there by bicycle. It took us just 10 minutes.

We were surprised because the parking area was very crowded, much crowded than every day. We had to wait a long time to put our bicycles there. Then we went into the market.

First, we went to the food shops. There are many kinds of food such as hat dua [water melon seeds], sugar coated fruit, cake, candy ... They look very delicious and the price is reasonable. (ginger jam: $45000 \mathrm{VND} / \mathrm{kg}$, hat dua: $72000 \mathrm{VND} / \mathrm{kg}$, chestnut: $230000 \mathrm{VND} / \mathrm{kg}$.) Hat dua and many other foods do not sell as well as every year because people think that it is not safe for health (contain melanin). However, some foods are certified safe such as Tan Ky hat dua (72000VND/kg). Some merchants said, "Although the price is rather high but people still buy very much. However, some goods the price decreases such as hat dua, jams.)

Besides, there are many many other goods such as clothes, shoes, hats, belts, ... Clothes at Dong Ba market are very beautiful and fashionable, but the price is very expensive so we didn't buy any clothes.

The market is very crowded. The atmosphere is very bustling but it is in confusion. Many people take the advantage to shoplift or pickpocket.

We left the market at $4 \mathrm{pm}$. We felt tired because of the crowds. We didn't buy anything today so we will go to the market again next week to buy food and clothes for the Lunar New Year. We hope to find cheap clothes.

\section{Appendix D}

\section{Sample Letters}

November $19^{\text {th }}, 2009$

Dear Phuc,

Tomorrow will be Teacher's Day. I want to visit my old teacher. She taught me when I learnt in grade 5 at primary school. Her name is Minh Ly. My teacher loved us like her children. Now I can't visit her since I have lost touch with her since 3 years. I miss her very much.

And you? Who's your favorite teacher? Are you going to visit your old teacher?

Your friend,

Phuong 
$20^{\text {th }}$ November, 2009

Dear Tien,

Hello! What's new?

Today is Teacher's Day. Do you visit your teachers? I visited my old teacher with all members in my old class. My teacher's name is Huong. She teaches English. I like her and respect her very much. Today my class buy many rose flowers, carnation flower and gift in order to present her. Although it is rainy and very cold, all member in my class fell very happy. In the afternoon, my class went out and eat many things. I think it is an impression day. Bye! Have a nice weekend.

Best wishes

Phuc

Dear Huyen,

Are you ok? Working at school all days was very tired, isn't it? In the morning, did you do the text well? In my opinion, it was very difficult.

I think we should try for the final text.

I hear you have just bought a moto. Congratulations!

What is it color? How much is it? Is it a Sirius?

Ah.. You must treat me.

I will wait for your invitation.

Love you.

Thao

December $22^{\text {nd }}$

Dear Teacher,

I'm writing some short lines to you. Now, what are you doing at 8 o'clock? I guess you are having dinner with your family.

This week, I'Il have a writing test. I hope my class will pass it easily.

On Christmas, will you organize a small party for us like on Halloween?

A few days ago, oil-gas price increased more and more. I think you must reduce mot thu mot it [little of everything]. Everything is bitter and bitter. Gold price is suddenly increasing. And a day, gold price had gone up the top.

It started having sunshine. I hate living in Hue. Hue's weather is unusual. And Hue's girls are influenced on a part.

Christmas season comes. That means I will face a hard exam. I must try my best to pass it. I'm very scared. I see credit learning gives me a lot of free time. But I don't know how to use up it. I had a library card. It's unfair for me. Books which I borrow always are not there. Someone borrowed but not return. So I have not yet read any books. I have read some magazines, articles...

That's my some short confidence. See you next letter. Good night!

Bye.

Kim Quy 


\section{Appendix E \\ Sample Self-evaluation Sheet}

Self-evaluation: Monitoring skills development

Date: December $15^{\text {th }}$

Skills being developed: Writing

My current level of confidence in this skill (circle 1)
1 very low
$\sqrt{ } 2$ low
3 ok
4 high
5 very high

Aspect of this skill I have already demonstrated

- I can write letters.

Goal

What I want to be able to do (aspects, sub-skills, qualities I want to develop):

- Write more letters.

- Letters are longer.

- Use dictionary less when writing

- Write more quickly

Record of progress

Note down steps in your development of this skill. It is up to you to decide what progress means for you. It could be the achievement of a personal goal (such as getting a particular mark for an assignment), or a small step towards one of your goals (such as asking a question in class for the first time, or developing a successful strategy for arriving on time if you find time management is a challenge.)

\begin{tabular}{|c|c|c|}
\hline Date & Achievement & How you know \\
\hline & $\begin{array}{l}\text { (What I can do now that I couldn't } \\
\text { before) }\end{array}$ & (evidence or example) \\
\hline $\begin{array}{l}\text { December } \\
22^{\text {nd }}\end{array}$ & $\begin{array}{l}\text { 1. Write seven letters a week. } \\
\text { 2. Write longer letters, more than half a } \\
\text { page. } \\
\text { 3. Use dictionary less. } \\
\text { 4. Write more quickly. }\end{array}$ & $\begin{array}{l}\text { 1. Now write } 6 \text { letters to language } \\
\text { partner, } 1 \text { letter to teacher. Last week, } 4 \\
\text { letters to friend, } 1 \text { letter to teacher. } \\
\text { 2. All letters are more than } 1 / 2 \text { page. } \\
\text { One letter more than } 1 \text { page. } \\
\text { 3. Look up only } 3-4 \text { words/letter } \\
\text { 4. Spend } 15 \text { minutes/letter. Before } 20 \text { - } \\
30 \text { minutes/letter. }\end{array}$ \\
\hline
\end{tabular}

